4 Yusef S, Ramsdale D, Peto R, et al. Early intravenous atenolol treatment in suspected acute myocardial infarction. Lancet 1980 ;ii:273-6.

${ }^{5}$ Norwegian Multicentre Study Group. Timolol-induced reduction in mortality and reinfarction in patients surviving acute myocardial infarction. N Engl F Med $1981 ; 304: 801-7$.

${ }^{6}$ Beta-Blocker Heart Attack Study Group. The beta-blocker heart attack trial-preliminary report. $\mathcal{F} A M A 1981 ; \mathbf{2 4 6}: 2073-4$.

' Hansteen V, Moinichen E, Lorentsen E, et al. One year's treatment with propranolol after myocardial infarction: preliminary report of Norwegian multicentre trial. Br Med f 1982;284:155-60.

${ }^{8}$ Sonnenblick EH, Ross J, Covell JW, Kaiser GA, Braunwald E. Velocity of contraction as a determinant of myocardial oxygen consumption. Am $\mathcal{F}$ Physiol 1965;209:919-27.

${ }^{9}$ Braunwald E. Thirteenth Bowditch lecture. The determinants of myocardial oxygen consumption. Physiologist 1969;12:65-93.

10 Chamberlain D. Effects of beta-adrenergic blockade on heart size. Am $\mathcal{F}$ Cardiol 1966;18:321-8.

11 Coltart DJ, Alderman EL, Robinson SC, Harrison DC. Effect of propranolol on left ventricular function, segmental wall motion and diastolic pressure-volume relation in man. Br Heart $\mathcal{7}$ 1975;37:357-64.

12 Dehmer GJ, Falkoff M, Lewis SE, Hillis LD, Parkey RW, Willerson JT. Effect of oral propranolol on rest and exercise left ventricular ejection fraction, volumes, and segmental wall motion in patients with angina pectoris. Assessment with equilibrium gated blood pool imaging. $\mathrm{Br}$ Heart $\mathcal{F} 1981 ; 45: 656-6$.
13 White C de B, Udwadia BP. Beta-adrenoceptor blockade and alphaadrenergic potentiation. Br f Clin Pharmacol 1975;2:99-105.

${ }^{14}$ Richards DA, Prichard BNC. Clinical pharmacology of labetalol. $\mathrm{Br} \mathcal{F}$ Clin Pharmacol 1979;8:89-93.

15 Richards DA, Prichard BNC, Dobbs RJ. Adrenoceptor blockade of the circulatory responses to intravenous isoproterenol. Clin Pharmacol Ther $1978 ; 24: 264-73$.

${ }^{16}$ Dixon WJ, Brown MB, eds. Biomedical computer programme-“P” series. Berkeley: University of California Press, 1979:540-80.

17 Winer BJ. Statistical principles in experimental design. 2nd ed. New York: McGraw-Hill, 1971:197-200.

${ }^{18}$ Reale A, Nigri A, Gioffre PA, Motolese M. Acute influence of different beta-blocking agents upon left heart haemodynamics at rest and during exercise in patients with coronary heart disease. Eur $\mathcal{F}$ Cardiol 1979;9: 101-9.

19 Taylor SH, Silke B, Lee PS. Intravenous beta-blockade in coronary heart disease: is cardioselectivity or intrinsic sympathomimetic activity haemodynamically useful ? $N$ Engl f Med $1982 ; 306: 631-5$.

${ }^{20}$ Koch G. Cardiovascular dynamics after acute and long-term alpha- and beta-adrenoceptor blockade at rest, supine and standing, and during exercise, Br 7 Clin Pharmacol 1979;8:101-5.

21 Taylor SH, Silke B. Haemodynamic effects of beta-blockade in ischaemic heart failure. Lancet 1981 ;ii:835-7.

(Accepted 6 May 1982)

\title{
Maternal anti-D concentrations and outcome in rhesus haemolytic disease of the newborn
}

\author{
P BOWELL, J S WAINSCOAT, T E A PETO, H H GUNSON
}

\begin{abstract}
The relation between maternal anti-D concentrations, measured against the British working standard, and outcome of rhesus-sensitised pregnancies was studied. There is a clear relation between increasing anti-D concentrations and the chance of a severely affected baby. Of those pregnancies (78) where serial anti-D concentrations remained below $4 \mathrm{IU} / \mathrm{ml}$, no baby had a cord haemoglobin below $10 \mathrm{~g} / \mathrm{dl}$ and three had exchange transfusions. In contrast, of those mothers (106) with anti-D concentrations above $4 \mathrm{IU} / \mathrm{ml}, 23 \mathrm{had}$ babies with a cord haemoglobin below $10 \mathrm{~g} / \mathrm{dl}$ and 79 babies had exchange transfusions.

It is suggested that those pregnancies where anti-D concentrations remain below $4 \mathrm{IU} / \mathrm{ml}$ represent a relatively safe group in which amniocentesis may be avoided.
\end{abstract}

\section{Introduction}

In spite of prophylaxis, rhesus haemolytic disease of the newborn remains an appreciable clinical problem. ${ }^{12}$ The management of affected pregnancies is helped by a prediction of outcome, which

\footnotetext{
Oxford Regional Blood Transfusion Centre, John Radcliffe Hospital, Headington, Oxford OX3 9DU

P BOWELL, FIMLS, chief medical laboratory scientific officer

H H GUNSON, FRCPATH, DSC, director (present position: director, Northwest Regional Transfusion Service, Manchester)

Nuffield Department of Clinical Medicine, John Radcliffe Hospital, Headington, Oxford OX3 9DU

J S WAINSCOAT, MRCP, MRCPATH, MRC training fellow

T E A PETO, MRCP, DPHIL, MRC training fellow
}

is conventionally based on previous history, some measure of maternal anti-D potency, and, in selected cases, examination of amniotic fluid. The estimation and interpretation of anti-D potency has been problematic for several reasons: the older manual titration method gives poor reproducibility, ${ }^{3}$ the early automated method of quantification ${ }^{4}$ required several modifications, ${ }^{56}$ and different anti-D standards have been used in Britain for the automated quantification method. A British anti-D working standard (coded 72/229) was established in 1975, however, and virtually all laboratories have now adopted this preparation for determination of antenatal anti-D concentrations.

We examined the relation between maternal anti-D concentrations and outcome of rhesus-sensitised pregnancies in the Oxford region. This is the first such study to report anti-D concentrations measured, with the above modifications, directly against the British anti-D working standard.

\section{Patients and methods}

From 1977 to 1980 all pregnant women in the Oxford region were screened for red cell antibodies, principally at the Oxford Regional Transfusion Centre but also at several of the district hospitals. During this period 380 women were found to have anti-D antibodies: details of relevant investigations were routinely sent to the Oxford Regional Transfusion Centre and sufficient data for study was available from 260 patients. The remaining 120 were excluded for the following reasons: only one anti-D concentration determined (60), anti-D detectable by enzyme-modified cells only (level $<0.05 \mathrm{IU} / \mathrm{ml}$ ) (35), insufficient information (14), incidental abortions (six), anti-D found only at birth (four), rhesus-positive patient with $0.75 \mathrm{IU} / \mathrm{ml}$ anti-D (one)

Cord haemoglobin and bilirubin concentrations were measured, $\mathrm{ABO}$ and rhesus blood group determined, and direct antiglobulin tests performed in hospital laboratories by standard methods. Automated anti-D quantification was performed using an autoanalyser (Technicon) and based on the method of Marsh et al $l^{4}$ using the modifications recommended by Gunson et al. ${ }^{5} 6$ In addition, a cell concen- 
tration of $5 \%$, an interference filter of $410 \mathrm{~nm}$, and a flow cell $8 \mathrm{~mm}$ long were substituted for those described by Marsh. The haemagglutinating activity of the test sera was compared with that of the British anti-D working standard (72/229). A second standard preparation was included in each test run to control the primary working standard. A variation of the secondary standard value from its established mean value of $>10 \%$ (2 standard deviations) required that the whole test run should be repeated.

\section{Results}

During the study there were 109000 births in the Oxford region. Seven babies died from haemolytic disease of the newborn, $(0.07 / 1000$ births) and 380 women were found to have anti-D antibodies during pregnancy ( $3 \cdot 5 / 1000$ births). Of these 380 women, 260 were studied in detail. Five pregnancies were managed with intrauterine transfusion: two babies survived (initial anti-D concentrations of $7.9 \mathrm{IU} / \mathrm{ml}$ and $28 \mathrm{IU} / \mathrm{ml}$ ) and three died (initial anti-D concentrations of $45 \mathrm{IU} / \mathrm{ml}$, $104 \mathrm{IU} / \mathrm{ml}$, and $104 \mathrm{IU} / \mathrm{ml}$ ). Four pregnancies were managed with plasmapheresis: two babies survived (initial anti-D concentrations of $32 \mathrm{IU} / \mathrm{ml}$ and $71 \mathrm{IU} / \mathrm{ml}$ ) and two died (initial anti-D concentrations

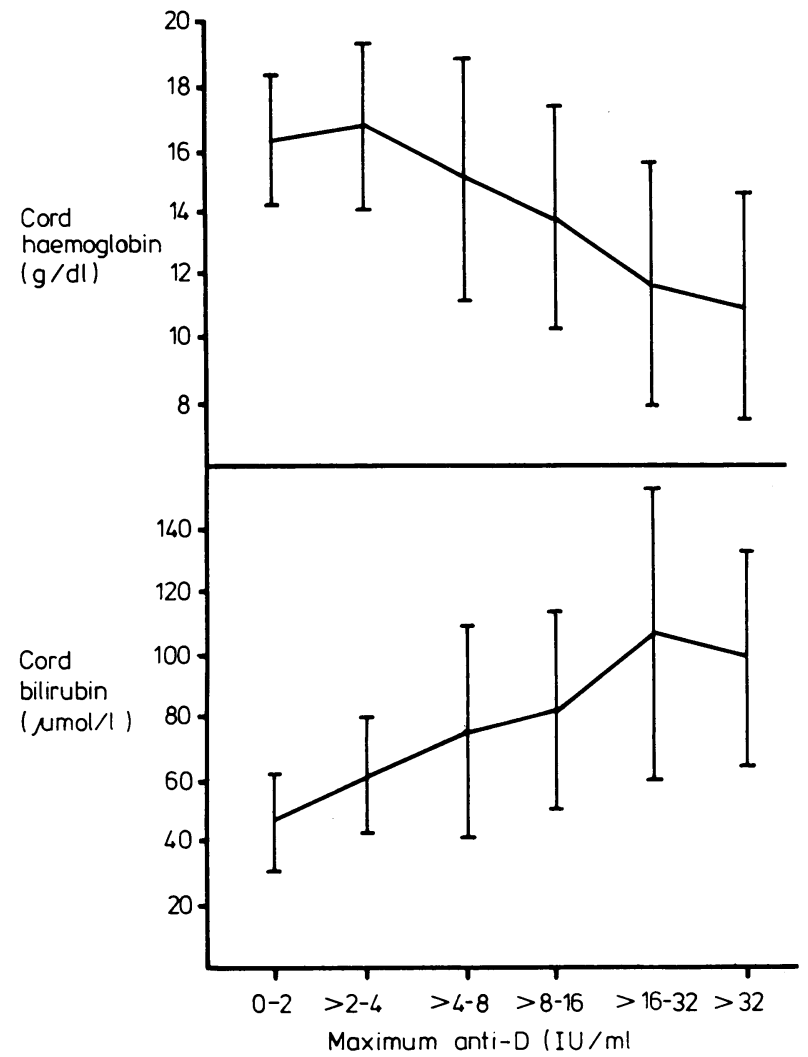

FIG 1-Cord haemoglobin and cord bilirubin concentrations $( \pm S D)$ at different maximum maternal anti-D concentrations. No of cases in each group are same as in fig 2 .

Conversion: SI to traditional units-Bilirubin: $1 \mu \mathrm{mol} / 1 \approx$ $0.06 \mathrm{mg} / 100 \mathrm{ml}$.

TABLE I-No of rhesus-sensitised women with rhesus-positive or rhesus-negative babies according to percentage change in anti- $D$ concentrations during pregnancy

\begin{tabular}{lcccc}
\hline & \multicolumn{2}{c}{ Change in anti-D concentrations* } & \\
\cline { 2 - 4 } $\begin{array}{l}\text { Rhesus } \\
\text { (babies) }\end{array}$ & $\begin{array}{c}\text { Decrease } \dagger \\
>50 \%\end{array}$ & $\begin{array}{c}\text { Within } \\
50 \%\end{array}$ & $\begin{array}{c}\text { Increase } \\
>50 \%\end{array}$ & Total \\
\hline $\begin{array}{lcccc}\text { Positive } \\
\text { Negative }\end{array}$ & 4 & 55 & 125 & 184 \\
\hline Total & 24 & 42 & 0 & 66 \\
\hline
\end{tabular}

*100 (maximum - minimum) $\div$ minimum

$\dagger$ Minimum occurs after maximum.
$260 \mathrm{IU} / \mathrm{ml}$ and $345 \mathrm{IU} / \mathrm{ml}$ ). There was one intrauterine death with an initial anti-D at 16 weeks of $4.6 \mathrm{IU} / \mathrm{ml}$, which at the time of death $(28$ weeks) had risen to $168 \mathrm{IU} / \mathrm{ml}$.

The remaining 250 pregnancies resulted in live births; amniocentesis was performed at the clinician's discretion. One baby died shortly after birth (gestation 28 weeks, cord haemoglobin concentration $2 \cdot 7$ $\mathrm{g} / \mathrm{dl}$, maximum maternal anti-D $28 \mathrm{IU} / \mathrm{ml}$ ). The average number of anti-D estimations per pregnancy was six (range two to 16). These 250 pregnancies resulted in 184 rhesus-positive and 66 rhesus-negative babies. Table I shows the relation of maternal anti-D concentrations to the rhesus D group of the baby. Serial determinations of anti-D show that a rise of greater than $50 \%$ during pregnancy is highly suggestive of a rhesus-positive baby. A fall of greater than $50 \%$ is less strongly suggestive of a rhesus-negative baby. Maternal anti-D

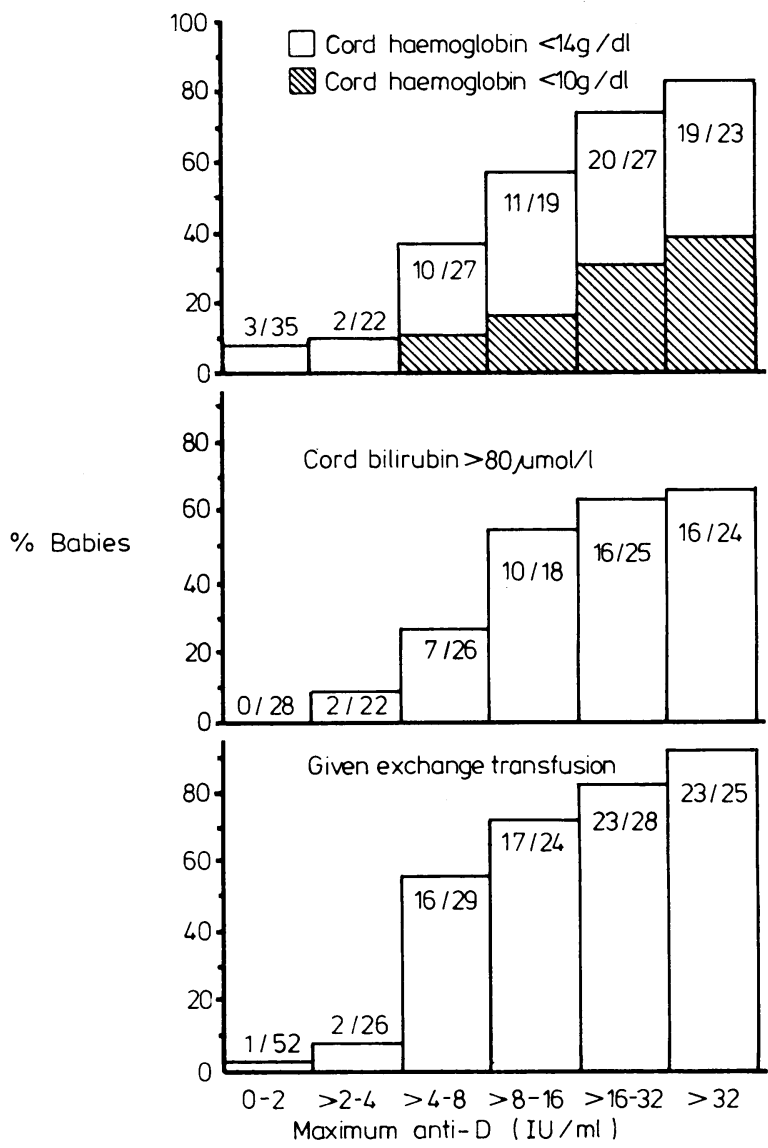

FIG 2-Percentage of babies severely affected with haemolytic disease of the newborn at different maximum maternal anti-D concentrations. Numbers represent exact numbers of babies affected and studied.

concentrations showed little change in about one-third of the pregnancies producing rhesus-positive babies and two-thirds of those producing rhesus-negative babies.

It was decided to use maximum anti-D concentrations, a clinically simple value, to predict the outcome of the pregnancy. We were unable to improve the predictive power of maximum anti-D concentrations by taking the rate of rise of anti-D concentrations or the gestation into consideration. For the purposes of subsequent analysis, therefore, the pregnancies resulting in rhesus-positive babies were divided into the following groups based on maximum anti-D concentrations: 52 with maximum concentrations of $0-2 \mathrm{IU} / \mathrm{ml}, 26$ with concentrations of $2-4$ $\mathrm{IU} / \mathrm{ml}, 29$ with $4-8 \mathrm{IU} / \mathrm{ml}, 24$ with $8-16 \mathrm{IU} / \mathrm{ml}, 28$ with $16-32 \mathrm{IU} / \mathrm{ml}$, and 25 with over $32 \mathrm{IU} / \mathrm{ml}$.

Figure 1 shows the relation of maximum anti-D concentrations to cord haemoglobin and bilirubin concentrations. There is a clear relation between the maximum anti-D concentrations and the mean values of these cord parameters. The clinical value of anti-D measurements was examined by relating the severity of haemolytic disease of the newborn to maximum anti-D concentrations. The severity of the 
disease was judged in terms of cord haemoglobin value below $10 \mathrm{~g} / \mathrm{dl}$ and below $14 \mathrm{~g} / \mathrm{dl}$, cord bilirubin values above $80 \mu \mathrm{mol} / \mathrm{l}(4.7 \mathrm{mg} / 100$ $\mathrm{ml}$ ), and the incidence of exchange transfusions. Figure 2 shows the probability of a severe outcome, by this definition, with maximum anti-D concentrations. The chance of a baby being severely affected is related to anti-D concentrations, with a considerably increased likelihood of such an outcome when the maximum anti-D concentration is above $4 \mathrm{IU} / \mathrm{ml}$.

The cord haemoglobin and bilirubin concentrations and the treatment of babies was analysed with respect to the mothers' previous history of babies with haemolytic disease of the newborn (see table II for analysis of cord haemoglobin). After controlling for maximum anti$D$ concentrations, there was no difference in outcome for mothers either with or without a past history of haemolytic disease of the newborn.

TABLE II-Cord haemoglobin concentrations of rhesus-positive babies of mothers with and without a previous history of babies with haemolytic disease of the newborn. Mothers are grouped according to maximum anti-D concentrations and results are means $\pm S E M$ (numbers of babies in parentheses)

\begin{tabular}{ccc}
\hline & \multicolumn{2}{c}{ Mean cord haemoglobin $(\mathrm{g} / \mathrm{dl})$} \\
\cline { 2 - 3 } $\begin{array}{c}\text { Maximum anti-D } \\
(\mathrm{IU} / \mathrm{ml})\end{array}$ & $\begin{array}{c}\text { No previous history of } \\
\text { haemolytic disease of the } \\
\text { newborn }\end{array}$ & $\begin{array}{c}\text { Previous history of } \\
\text { haemolytic disease of the } \\
\text { newborn }\end{array}$ \\
\hline $0-2$ & $15 \cdot 9 \pm 0.36(24)$ & $17 \cdot 0 \pm 0.75(10)$ \\
$>2-4$ & $16.9 \pm 0.70(17)$ & $16.4 \pm 0.49(5)$ \\
$>4-8$ & $15.5 \pm 1.09(16)$ & $15.0 \pm 1.07(8)$ \\
$>8-16$ & $13.0 \pm 0.88(7)$ & $14.4 \pm 1.35(9)$ \\
$>16-32$ & $12.5 \pm 1.02(10)$ & $11.6 \pm 0.82(12)$ \\
$>32$ & $11.1 \pm 1.14(13)$ & $11.2 \pm 1.13(8)$ \\
\hline
\end{tabular}

\section{Discussion}

These results show the continuing morbidity and mortality of rhesus haemolytic disease of the newborn. To determine the value of anti-D measurements in the management of rhesussensitised pregnancies we analysed serial concentrations of anti$D$ against outcome of pregnancy.

The anti-D concentrations were measured by the Technicon AutoAnalyzer using a modern assay calibrated directly against the British anti-D working standard (72/229). Previous reports on maternal anti-D concentrations and outcome have used various standards and different units and their results are therefore difficult to compare with ours. ${ }^{7-11}$

Outcome of pregnancy was assessed by reference to cord haemoglobin and bilirubin concentrations and to the incidence of exchange transfusion, all of which give a similar association with anti-D concentrations. It was, therefore, felt unnecessary to adopt more complex indices of haemolytic disease of the newborn. The results confirm that increasing concentrations of anti-D are associated with an increasing risk of a severely affected baby. There is, however, a large individual variation of outcome with maximum anti-D concentrations; this may relate to factors such as the rate of transfer of antibody across the placenta, period of contact with the antibody, rhesus genotype of the fetus, and the fetal response to haemolysis. We were unable to show that a previous history of haemolytic disease of the newborn accounted for any of the variation.

In sensitised pregnancies resulting in rhesus-negative babies, maternal anti-D concentrations would be expected to remain the same or to fall due to the increase in plasma volume and natural decline in antibody production. Those small increases seen in this group are probably attributable to the level of reproducibility of the technique $(+20 \%) .{ }^{5}$ In rhesus-positive cases these factors still operate but are often masked by sensitisation causing further increases in anti-D concentrations. Present results show that serial anti-D concentrations cannot predict a rhesus-negative baby with confidence, though rises of anti-D greater than $50 \%$ do indicate a rhesus-positive baby.

Although serial anti-D concentrations cannot define the group of pregnancies resulting in rhesus-negative babies we were able to define a relatively safe group of pregnancies where serial anti-D concentrations remain below $4 \mathrm{IU} / \mathrm{ml}$.
Of 78 such pregnancies resulting in rhesus-positive babies no baby had a cord haemoglobin below $10 \mathrm{~g} / \mathrm{dl}$; only three required exchange transfusion and in two of these there was good evidence of $\mathrm{ABO}$ haemolytic disease. We were not able to define a group of pregnancies associated with a high risk of fetal or neonatal death from our study as the total number of deaths was too small, though others have attempted such predictions. ${ }^{8} 11$

This study shows the relation between maternal anti-D concentrations and outcome and should help in the management of rhesus-sensitised patients. We recommend that regular blood samples are taken fortnightly after the 20th week of gestation. This is of value in detecting sudden rises of anti-D and in deciding on the need for amniocentesis. Our results suggest that amniocentesis, known occasionally to cause secondary immunisation, ${ }^{12} 13$ could be avoided in low-risk patients.

Requests for reprints to $\mathrm{P}$ Bowell.

We thank those obstetricians and haematologists within the Oxford region who provided clinical data for this study; Dr C C Entwistle for his helpful criticism of the paper; and Helen Wilkes and Dr M Bulmer, University of Oxford, for statistical help.

\section{References}

1 Clarke C, Whitfield AGW. Deaths from rhesus haemolytic disease in England and Wales in 1977: accuracy of records and assessment of anti-D prophylaxis. $\mathrm{Br}$ Med $\mathcal{F}$ 1979;i:1665-9.

2 Tovey LAD, Taverner JM. A case for the antenatal administration of anti-D immunoglobulin to primigravidae. Lancet $1981 ; \mathrm{i}: 878-81$.

${ }^{3}$ Goldsmith KLG, Mourant AE, Bangham DR. The international standard for anti-Rho (anti-D) incomplete blood-typing serum. Bull WHO $1967 ; 36: 435-45$.

4 Marsh WL, Nichols M, Jenkins WJ. Automated detection of blood group antibodies. Fournal of Medical Laboratory Technology 1968;25:335-42.

5 Gunson HH, Phillips PK, Stratton F. Observations on the reproducibility of the bromelised test cell anti-D assay using the auto-analyser. Vox Sang $1974 ; 26: 334-43$.

${ }^{6}$ Gunson HH, Phillips PK, Stratton F. The importance of equilibrium constant and heterogeneity index on anti-Rho (D) quantitation using the auto-analyser. Vox Sang $1976 ; 30: 364-78$

7 Tovey LAD, Haggas WK. Prediction of the severity of rhesus haemolytic disease by means of antibody titrations performed on the Autoanalyzer. Br $\mathcal{F}$ Haematol $1971 ; 20: 25-33$.

${ }^{8}$ Fraser ID, Tovey GH, Lockyer WJ, Sobey DF. Antibody protein levels in the maternal serum in Rhesus isoimmunization. $\mathcal{f}$ Obstet Gynaecol Br Commonw 1972;79:1074-9.

9 Douglas R, Staveley JM. Quantitative measurement of anti-D during pregnancy using a low ionic strength autoanalyser system. NZ Med $\mathscr{f}$ $1972 ; 76: 184-6$.

${ }^{10}$ Morley G, Gibson M, Eltringham D. Use of discriminant analysis in relating maternal anti-D levels to the severity of haemolytic disease of the newborn. Vox Sang 1977;32:90-8.

11 Tomlinson J, James V, Wagstaff W. A survey of maternal anti-D levels related to H D N B [Abstract]. Br 7 Haematol $1981 ; \mathbf{4 9}: 130$.

12 Pridmore BR, Robertson EG, Walker W. Liquor bilirubin levels and false prediction of severity in rhesus haemolytic disease. $\mathrm{Br}$ Med $\mathcal{F} 1972$;iii: 136-9.

13 Zipursky A, Pollock J, Chown B, Israels LG. Transplacental foetal haemorrhage after placental injury during delivery or amniocentesis. Lancet 1963;ii:493-4.

(Accepted 20 May 1982)

ONE HUNDRED YEARS AGO Dr Dutrieux, the Belgian explorer, writes, under date Alexandria, July 20th:-“' "I have escaped the massacres perpetrated by the criminals and Bedouins let loose by Arabi Pasha against a defenceless population. My house has been burnt and pillaged. As medical officer of the Government Hospital and of the European Hospital, my professional duties detained me in Alexandria, which I have not quitted for a single minute." $\mathrm{Dr}$ Dutrieux's devotion to his duties has been fitly rewarded by the Khedive, who has conferred upon him proprio motu the title of Bey, and the appointment of Physician-in-Chief to the Egyptian Government Hospital.

(British Medical fournal, 1882.) 